Supporting information - Manuscript JM061133J

\title{
Synthesis and Biological Evaluation of
}

Selective Aromatase Expression Regulators in Breast Cancer Cells

Bin Su, Serena Landini, Danyetta D. Davis, and Robert W. Brueggemeier

Elemental Analysis Values

\begin{tabular}{|c|c|c|c|c|c|c|c|}
\hline & & Calculat & & & Found & & \\
\hline Compound & Formula & $\mathbf{C}$ & $\mathbf{H}$ & $\mathbf{N}$ & $\mathbf{C}$ & $\mathbf{N}$ & $\mathbf{H}$ \\
\hline 1f & $\mathrm{C}_{15} \mathrm{H}_{16} \mathrm{~N}_{2} \mathrm{O}_{5} \mathrm{~S}$ & 53.56 & 4.79 & 8.33 & 53.54 & 4.80 & 8.10 \\
\hline $2 c$ & $\mathrm{C}_{15} \mathrm{H}_{15} \mathrm{~N}_{3} \mathrm{O}_{7} \mathrm{~S}$ & 47.24 & 3.96 & 11.02 & 46.86 & 4.05 & 10.99 \\
\hline $3 c$ & $\mathrm{C}_{19} \mathrm{H}_{18} \mathrm{~N}_{2} \mathrm{O}_{5} \mathrm{~S}$ & 59.06 & 4.70 & 7.25 & 58.77 & 4.70 & 6.78 \\
\hline $4 c$ & $\mathrm{C}_{21} \mathrm{H}_{20} \mathrm{~N}_{2} \mathrm{O}_{5} \mathrm{~S}$ & 61.15 & 4.89 & 6.79 & 61.27 & 4.94 & 6.46 \\
\hline $5 c$ & $\mathrm{C}_{16} \mathrm{H}_{18} \mathrm{~N}_{2} \mathrm{O}_{5} \mathrm{~S}$ & 54.85 & 5.18 & 7.99 & 55.10 & 5.21 & 7.77 \\
\hline $8 c$ & $\mathrm{C}_{15} \mathrm{H}_{15} \mathrm{FN}_{2} \mathrm{O}_{5} \mathrm{~S}$ & 50.84 & 4.27 & 7.91 & 50.54 & 4.26 & 7.74 \\
\hline $12 b$ & $\mathrm{C}_{15} \mathrm{H}_{16} \mathrm{~N}_{2} \mathrm{O}_{5} \mathrm{~S}$ & 53.56 & 4.79 & 8.33 & 53.20 & 4.81 & 8.19 \\
\hline
\end{tabular}

